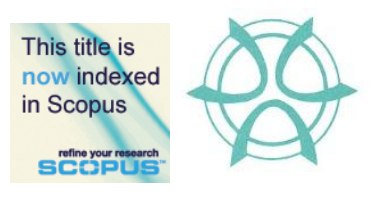

PLANNING MALAYSIA:

Journal of the Malaysian Institute of Planners

Volume XII (2014), Page 19 - 34

\title{
TOWN PLANNERS' PERCEPTIONS OF SPORTS FACILITIES AND URBAN DEVELOPMENT: A CASE STUDY OF 13 STATES' MAIN SPORTS FACILITIES IN MALAYSIA
}

\author{
Maassoumeh Barghchi ${ }^{1}$ \& Dasimah Omar ${ }^{2}$ \\ ${ }^{1}$ Faculty of Art and Islamic Architecture \\ IMAM REZA INTERNATIONAL UNIVERSITY, MASHHAD, IRAN \\ ${ }^{2}$ Faculty of Architecture, Planning \& Surveying \\ UNIVERSITI TEKNOLOGI MARA (UITM), SHAH ALAM, MALAYSIA
}

\begin{abstract}
Sport is defined as recreation and is considered as the symbol of developed degree of a country and economic development. However, globalisation and dramatic growth of urbanisation highlight the importance of sport and sports facilities in cities. On the other hand, there is a recent trend in some countries to build sports facilities not only for their intended sporting purpose but also for the twin aim of stimulating urban areas. In Malaysia, sports and sports facilities have improved rapidly over the past years. There is also currently tremendous interest in sports and a wave of sports investment. This research aims to examine town planners' perceptions of sports facilities and urban development focusing on the main sports facilities at State level in Malaysia. It is based on quantitative research via postal questionnaire survey and key informant interviews. The research reveals new trend of sports investment and sports facilities construction started in the mid-1990s. The findings of this research elaborate new considerations for town planners to determine the type of local environment for a new sports facility. Further, it may assist to review and provide specific guidelines and principles for sports facilities in Malaysia to follow the global trend in the future.
\end{abstract}

Keyword: Town planners, sports facilities, urban development

\footnotetext{
${ }^{1}$ Post Graduate Student at Universiti Teknologi Mara (UiTM), Shah Alam, Malaysia

${ }^{2}$ Professor at Faculty of Architecture, Planning \& Surveying.

Email : dasimah629@salam.uitm.edu.my
} 
Maassoumeh Barghchi \& Dasimah Omar

Town Planners' Perceptions of Sports Facilities and Urban Development: A Case Study of 13 States' Main Sports Facilities in Malaysia

\section{INTRODUCTION}

Sport is defined as recreation involving the active production of leisure (Haywood et al. 1991). Leisure is mentioned as "the symbol of developed degree of country" and "leisure sports" as "the production of modern society" (Min \& Jim 2010, p. 99). According to Aman (2005, p. 15), economic development "plays a significant role in leisure, recreation and sport sectors." Most of the literature on sports, sports facilities and their impacts comes from the experience of developed world (Chen 2006). On the other hand, globalisation and dramatic growth of urbanisation in low-and mid-income countries in the next few decades (Beall \& Fox 2009) highlight the importance of sports and sports facilities in cities.

In Malaysia, sports and sports facilities have improved rapidly over the past years, especially after the country hosted the 16th Commonwealth Games in 1998 (Megat Daud 2007). The increase in the amount of public money being spent on sports facilities, and at the same time, the increase in the number of sports facilities in Malaysia necessitate an investigation into the issues surrounding the development of sports facilities.

A number of different terms have been used for places related to sports, e.g., stadium, arena, sports venue, and sports complex. The term sports facility is used in this research. According to Webster's New World College Dictionary, facility is defined as "a building, special room, etc. that facilitates or makes possible some activity" (Agnes \& Guralnik 2004). Sports facilities define the equipment and buildings for playing sports, e.g., tennis courts and swimming pools. This research focused only on sports facility as any enclosed facility where sports are played, where sports events can be hosted, which needs public money for construction and maintenance, and is large enough to require ancillary construction. Therefore, the study focused on the main sports facilities at state level in Malaysia.

In order to achieve the aim of the research, which is to examine the town planners' perception of sports facilities and urban development, the first step was to investigate the existing sports facilities. The questionnaires were sent to the City Councils of the 13 state capitals, specifically to the chief town planner and to the manager of the main sports complex in each state. Further, heads of 13 State Departments of Youth and Sports and Sports Councils. Secondly, to gather the perceptions of town planners by sending out a questionnaire to specific government agencies in Kuala Lumpur and all 13 states responsible for formulating and administering all national policies relating to town and country planning. Thirdly, direct 
interviews were carried out with four key personnel from the Ministry of Youth and Sports, the Ministry of Housing and Local Government, the National Sports Council and the Department of Town and Country Planning. Information obtained from these interviews was triangulated with the data gathered from the postal survey, which was carried out during April and May 2010. The research is structured as follows. The next section reviews the current literature on sports facilities development. The third section concentrates on research methodology. The findings are provided in section four. Finally, discussion and conclusion extract lesson from empirical investigation.

\section{THEORETICAL BACKGROUND}

Sport is influenced by the process of globalisation in several ways such as internationalisation of sports competitions, international diffusion of sports, sports mega events (Aminuddin \& Parilah 2008), and emergence of international organisations (Aman 2005). Sports facilities have changed through the years from functional facilities, adapted facilities, state-of-the art facilities to centre of business and regenerating area facilities (Aymeric Magne Stadiums Consulting Group [AMSCG] 2009). After the new Olympic movement, was proclaimed in 1894 (Horne et al. 1999), sports have emerged in their modern forms and the sports facilities have evolved into one of the great public building forms of the twentieth century, regarded, at their best, as an essential and positive element of civic life (John et al. 2007).

Most of the literature on sports facilities draws upon North American experiences as professional sports facilities there are very popular. The construction boom in sports facilities started in the 1990s in America (Fried 2005). These facilities were developed by local areas to attract professional sports teams and franchises from other cities and considerable public funds from local taxpayers' money were devoted to these projects (Thornley 2002). While in the US, cities compete with each other for sports investment, in the UK sports facilities are national public investment or funded by public-private partnership (Suzuki 2007).

In the 1970s and 1980s, most countries' expenditure on sport expanded considerably with the rationale that sport made an important contribution to local communities in welfare terms (Gratton \& Taylor 1991). On the other hand, following the 'bricks and mortar' approach over the past 
Maassoumeh Barghchi \& Dasimah Omar

Town Planners' Perceptions of Sports Facilities and Urban Development: A Case Study of 13 States' Main Sports Facilities in Malaysia

two decades, the single most popular city centre redevelopment project to emerge in urban America has been the sports stadium (Chapin 1999). In the $\mathrm{UK}$, in the late $1980 \mathrm{~s}$, a second wave of sports investment began with a similar rationale. However, several cities built prestigious sports-led development, using enterprise-led development policies, to promote economic and regional development (Davies 2002; Jones 2001; Lawless 1990; Loftman \& Nevin 1995). There is a recent trend in some countries to build sports facilities not only for their intended sporting purpose but also for the twin aim of stimulating urban areas (Davies 2005; Suzuki 2007). Nowadays an increasing number of developed and developing cities are promoting the cultural dimension - the arts, entertainment, festivals, leisure, tourism - and remaking cities as 'places to play' (Eisinger 2000). According to Davies $(2005$, p. 3$)$, "Sport has transcended the boundary from being considered as an active leisure pastime to being recognised as having considerable social and economic influence in contemporary society."

Malaysia gained its independence from the British in 1957, after more than 400 years of colonial rule since 1511. Since Independence, the country's economy had undergone a tremendous change from a basic agricultural economy to a new industrialised country (Chan 1997; Lai 1997). Malaysia's former Prime Minister Dr. Mahathir Mohamed was the leader who was most active in engaging the design of the built environment in the service of nation-building (Che' Man et al. 2013). As mentioned by Moser (2010, p. 288), "Mahathir's nationalist vision had a lasting impact on the course of Malaysian urbanism." In 1991, the Prime Minister announced the formation of 'Vision 2020' which stressed the importance of the Malaysia Incorporated Policy, in achieving the national goal of becoming an industrialised nation (Abdullah 1997). As part of 'Vision 2020', the year at which Malaysia is intended to achieve a developed country status, several spectacular mega-projects have been undertaken (Ahmad et al. 2013). Subsequently, there is currently tremendous interest in sports and a wave of sports investment. The constant increase of the allocation for sports programmes by the government reveals the increasing importance placed on sport in the country. The total allocation for sports programmes from 1986 to 1990 was RM97 million, although only RM49 million was actually spent. Nevertheless, in the Sixth Malaysia Plan (1991-1995), the allocation was increased to RM179 million, to become the third highest programme allocation after the Public Housing Programme (RM803 million) and the Fire Services Programme (RM193 million) (Government of Malaysia 1991). The budget allocation for sports development, under the Ninth Malaysian 
Plan (2006-2010), RM620.8 million, was more than double that of the allocation in the previous five-year plan period (2001-2005), RM307.2 million (Government of Malaysia 2006).

\section{RESEARCH METHODS}

The research described here is an applied exploratory research, using applied a mixed research design; this is a procedure for collecting, analysing and "mixing" both quantitative and qualitative data in a single study to understand a research problem (Bryman 1988; Creswell 2009, 2005, 2003). The research covered the sports facilities throughout Malaysia and the mailing approach is considered the best way to reach the selected samples due to limited time of the research. A total of 52 survey questionnaires were posted on June 8th 2009, followed by reminder letters together with another set of questionnaires on July 15th 2009. It was followed up by phone calls on September 15th 2009. Finally 25 replies out of 52, which form 48\%, were received by post. Of the total respondents, the majority, $40 \%$ (10), were town planners, $32 \%$ (8) the head of the Youth and Sports Departments, $16 \%$ (4) the head of Sports Councils, and only $12 \%$ (3) included the managers of sports facilities. The composition of the respondents who participated in the survey is presented in Table 6 .

Table 6: Category of Respondents

\begin{tabular}{lcc}
\hline \multicolumn{1}{c}{ Category of Respondents } & $\begin{array}{c}\text { No. of } \\
\text { Responses }\end{array}$ & Percentage \\
\hline The managers of main sports facilities, & 3 & 12.0 \\
Capital City Councils & 10 & 40.0 \\
Town planners, Capital City Councils & 8 & 32.0 \\
Departments of Youth and Sports & 4 & 16.0 \\
Sports Councils & 25 & 100.0 \\
\hline Total &
\end{tabular}

Secondly, the exploratory survey conducted on specific government's agencies either in Kuala Lumpur or in each of the 13 states, responsible for formulating and administrating all national policies relating to town and country planning. This section covers the planning offices throughout the country; therefore, the mailing approach has been considered the best way to reach the selected samples. The questionnaires were sent out to the above 
Maassoumeh Barghchi \& Dasimah Omar

Town Planners' Perceptions of Sports Facilities and Urban Development: A Case Study of 13 States' Main Sports Facilities in Malaysia

government's agencies on July 17 th 2009 , followed by postal reminder on September 8th, and phone reminder on September 30th 2009. Finally, there were 11 out of 15 questionnaires received by post which resulted in a $73 \%$ response rate. This response rate is considered as very high in this method. Further, to explore in depth the concepts of sports facilities and the concepts of decision making in Malaysia, key informant interviews were conducted with different persons. They were including Secretary-General of the Ministry of Youth and Sports, Policy Division, Ministry of Housing and Local Government, Properties and Facilities Division of the National Sports Council, and Research and Development Division of the Federal Department of Town and Country Planning.

\section{RESULTS AND DISCUSSION}

The analysis is presented in seven sections. These sections provide results and discussion of the data collected concerning the 13 states specific main sports facilities, as well as, town planners' perception of sports facilities and urban development. It uses triangulation of both qualitative and quantitative data to provide general comment regarding sports facilities in the Malaysian context.

\section{Trends of Sports Facilities Development}

The research findings reveal that more than half, 53.9\% (7), of the 13 states' main sports facilities were opened during 1995-2010. In addition, while $38.4 \%$ (5) of the existing sports facilities have had major renovation, all of this renovation has been done during 1995-2010. This is also to mention that, the rate of construction and renovation was higher during 1995-2004. This high percentage of construction and renovation underline the consideration and importance of sports facilities. This happened at the same time as hosting the 16th Commonwealth Games and the construction of sports facilities for that event. In Malaysia SUKMA Games are held once every two years in different states. It started since 1986. The first and second Games were held in Kuala Lumpur. However, following national trend, the increase in construction and renovation of sports facilities in the states has been due to hosting the SUKMA event. 
Therefore, the findings reveal the new trend for sports facilities construction which has started in the mid-1990s. However, it is due to the changing the role of sports facilities within the past 15 years. Firstly, sports facilities are constructed for hosting events. Secondly, sports facilities are there to develop harmony and unite people in line with the nation-building program. Thirdly, sports facilities are there for creating a sports culture to get the local community involved into sports. Finally, Vision 2020 requires having development in all aspects.

\section{Activities of Sports Facilities}

The result of the survey reveals that all of the 13 states' main sports facilities are multi-purpose. They use for sporting and non-sporting activities. As can be seen in the Figure 1, all of the sports facilities are used for national sports games, while $66.7 \%$ are used for international sports games, national official government events and national seminars and rallies. National concerts, exhibitions, expos, family days and ceremonies were selected by $33.3 \%$. All of the sports facilities have capacity of more than 1000 people. There are only $15.4 \%$ (2) out of 13 , with the capacity of more than 5000 people.

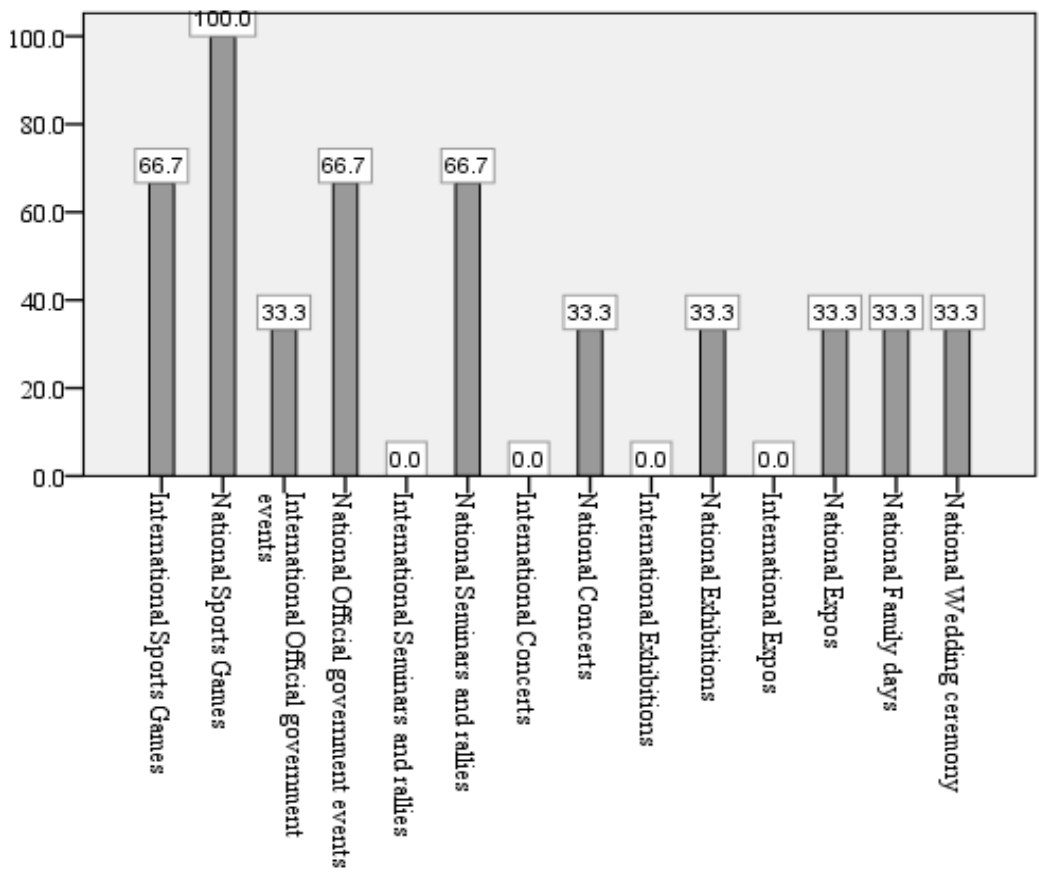

Figure 1: Activities 
Maassoumeh Barghchi \& Dasimah Omar

Town Planners' Perceptions of Sports Facilities and Urban Development: A Case Study of 13 States' Main Sports Facilities in Malaysia

\section{Location of Sports Facilities}

Sports facilities are located within the city areas. In the National Urbanisation Policy (2006-2020) sports complex are considered to be provided for urban hierarchies at national growth conurbation, regional growth conurbation, sub-regional growth conurbation, state growth conurbation and district growth conurbation. The $80 \%$ of the data gathered for this research comes from the sports facilities in $10 \mathrm{~km}$ or less than $10 \mathrm{~km}$ distance from the city centre. The most important factor for selecting the location of sports facilities is land availability as mentioned by majority of respondents.

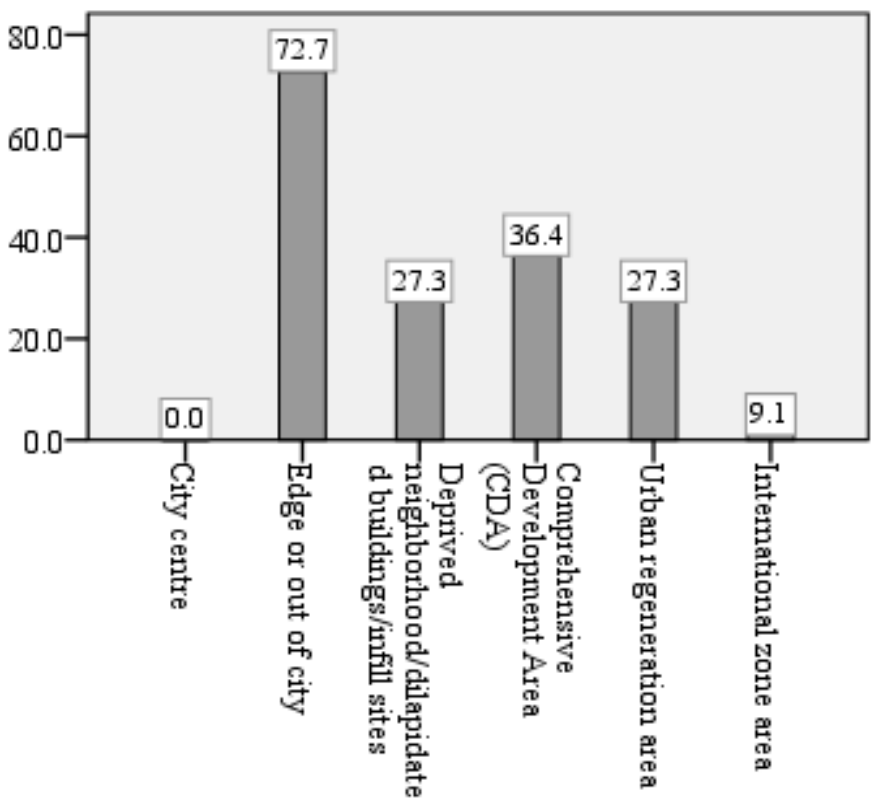

Figure 2: Optimal Site in the City

The findings on optimal site for the sports facilities reveal that majority of town planners, $81.8 \%$ (9), agreed on green-field site for sports facilities. In addition, the majority of town planners, $72.7 \%$ (8), agreed upon edge or out of city locations for optimal sports facilities sites. Comprehensive development area comes next at $36.4 \%$ (4). Deprived neighbourhoods mentioned by $27.3 \%$ (3), at the same level with urban regeneration areas. International zone areas gained the least choice from the respondents (Figure 2). 
It is clear that green-field sites and edge or out of city locations are considered by majority of the sample population as optimal sites for sports complexes. However, none of the respondents agreed upon city centre locations for sports complexes which underline a contrast with the international trend. It is due to sports complexes belong to public and necessitate public space. On the other hand, brown-field sites usually belong to private and there is not enough space in urban areas.

\section{Problems of Sports Facilities}

There were $75 \%$ (19) of the respondents who stated the income of the sports facility is not enough for maintenance costs. However, $83.4 \%$ (20) of the respondents mentioned to use tax money or having subsidy. In addition, lack of funds was quoted to be the most important problem of sports facilities stated by $52 \%$ (13) of the respondents. The question on the problems of the sports facilities reveals that, lack of activities was stated as the second important problem mentioned by $40 \%$ (10). It was followed by lack of public use and areas not fully utilised both at the same rate of $32 \%$ (8) (Figure 3).

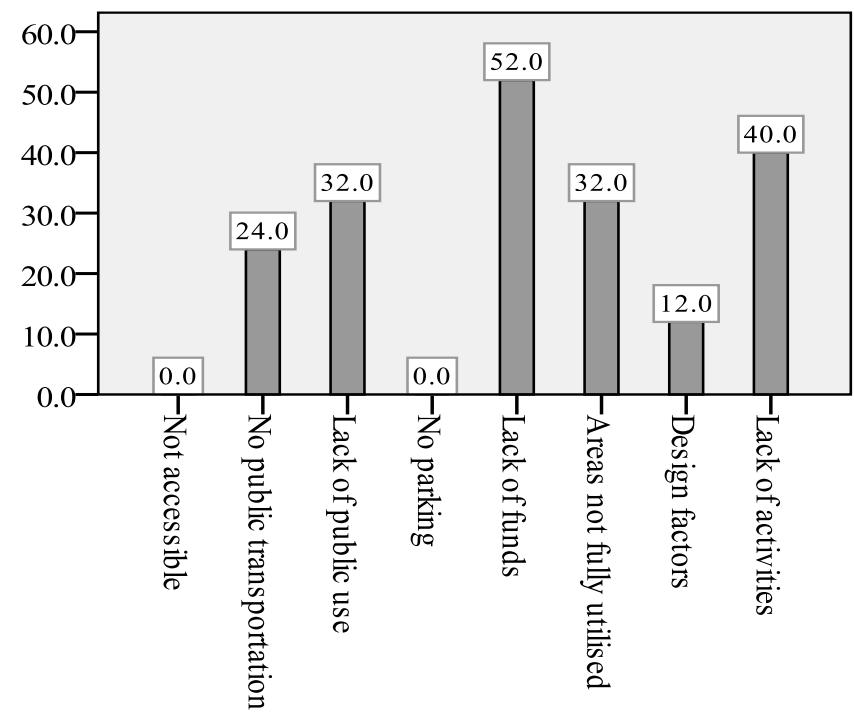

Figure 3: Problems 
Maassoumeh Barghchi \& Dasimah Omar

Town Planners' Perceptions of Sports Facilities and Urban Development: A Case Study of 13 States' Main Sports Facilities in Malaysia

More than half, 60\% (15), of the sports facilities have increased in their attendance rate. Only $20 \%$ (5) of respondents stated that the existing sports facilities do not have enough number of people attending the function. There were $76 \%$ (19) who were satisfied with the existing facilities enough for the people living there. Although, there were 44\% (11) believed that there is still a requirement for additional new sports facilities in the area.

\section{Site Selection Process of Sports Facilities}

The states government always proposes the site. The location and provision of recreational and sports facilities are identified in the Structure Plan prepared by local authorities based on population and standards for target people. The guidelines and planning standards prepared by the Federal Department of Town and Country Planning are used by local planning authorities in controlling activities in land development for uniform, comfortable and safe execution.

The research findings reveal that the guidelines and planning standards for sports facilities are prepared by the Federal Department of Town and Country Planning under the Ministry of Housing and Local Government based on population and urban hierarchy for every level of community. On the other hand, the required sports facilities are decided by the National Sports Policy provided by the Ministry of Youth and Sports. Further, the budget allocation is dedicated to sports by the Government through five-year plans. While the Federal Government is more on providing money for sports facilities construction, the State and Local Governments each provide land and layout, respectively. State authorities propose land and decide about the site selection of sports facilities. In addition, the land sometimes comes from federal or local authorities or the private sector.

\section{Rationales for Development of Sports Facilities}

Sporting events hosting was the main reason and rationale for sports facilities development in Malaysia, as can be seen in the Figure 4. It was due to the national trend regarding hosting the 16th Commonwealth Games. Significantly, SUKMA Games are hosted every two years by different states. As mentioned by town planners, benefit to local community and social developments were considered as following the main rationales for sports facilities development. The other factors selected by fewer respondents included necessity for the city, local or city landmark, local 
physical development and local economic development. In addition, the results from other group of respondents strength that sporting events is the main rationale, selected by $96 \%$ (24), to support sports facilities development in the states. Other factors including benefits to local community and social development are considered by more than half, $56 \%$ (14), of the respondent. This is in line with the national sport policy in Malaysia which encompasses both high performance sport and sports for all or mass sport for all strata of the community.

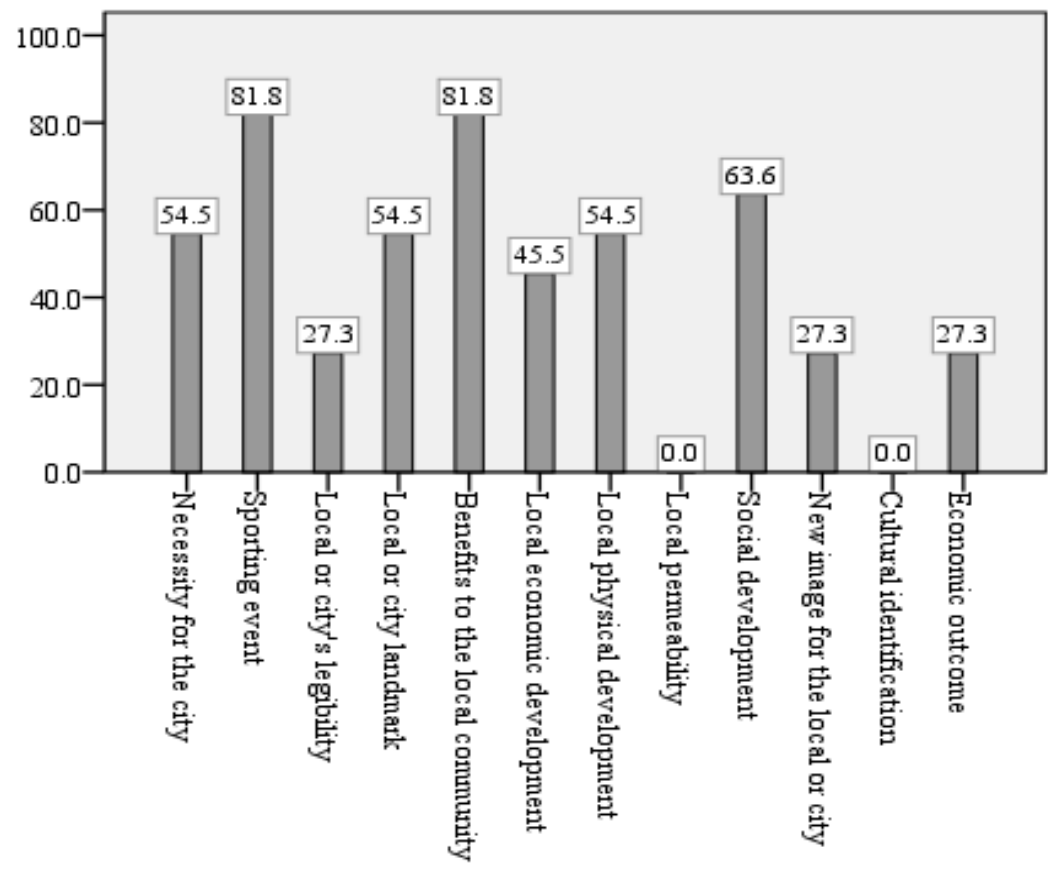

Figure 4: Rationales for Development

\section{Sports Facilities and Urban Development}

The research findings on the urban development strategy in Malaysia reveal the importance of residential, commercial and industrial aspects. Furthermore, none of the respondents chose the entertainment-based factor. The findings reveal that the majority of the town planners thought positively of the sport-centre urban development in Malaysia. There were only 18.2\% (2) moderately disagreeing and $9.1 \%$ (1) slightly disagreed. There were different types of development stimulated by sports facilities as mentioned by town planners. There are infrastructure, commercial, residential, informal 
Maassoumeh Barghchi \& Dasimah Omar

Town Planners' Perceptions of Sports Facilities and Urban Development: A Case Study of 13 States' Main Sports Facilities in Malaysia

sectors and entertainment ones, respectively. Accessibility was selected as the most important factor to improve the sustainability and to enhance the sports facilities impacts. It was then followed by public transportation, activities and the location of the sports facilities. There were more than half of the town planners, $54.5 \%$ (6), who agreed on physical development as the role of sports facilities in their surrounding area. It was followed by social development, $45.5 \%$ (5), and economic development mentioned by $36.4 \%$ (4) of the respondents.

Table 7: Sports-Centre Development

\begin{tabular}{lll}
\hline Agreement level & Frequency & Percentage \\
\hline Strongly Disagree & 0 & 0 \\
\hline Moderately Disagree & 2 & 18.2 \\
\hline Slightly Disagree & 1 & 9.1 \\
\hline Neither Agree Nor Disagree & 0 & 0 \\
\hline Slightly Agree & 3 & 27.3 \\
\hline Moderately Agree & 4 & 36.4 \\
\hline Strongly Agree & 1 & 9.1 \\
\hline Total & 11 & 100.0 \\
\hline
\end{tabular}

The results from the survey provide information on the type of development stimulated by sports complex construction. The research found that infrastructure development is the most significant factor as mentioned by $90.9 \%$ (10) of the respondents, followed by commercial at $63.6 \%$ (7). Residential and informal sector were chosen by $54.5 \%$ (6) and $45.5 \%$ (5) respondents, respectively. However, entertainment factor is chosen only by $27.3 \%$ (3) of the respondents which is the least chosen after industrial development factor that was not selected by any of the respondents. 


\section{CONCLUSION}

Findings from exploratory research on sports facilities development in the Malaysian context provides an insight into the sports facilities in Malaysia compare to other countries. The findings reveal new trend of sports investment and sports facilities construction started in the mid-1990s. However, with accordance to economic growth and 'Vision 2020' in Malaysia, it is consistent with the previous research. In addition, according to Min and Jin (2010) and Aman (2005), economic growth and developed degree of a country shows the role of leisure, recreation and sport in the country. Further, as mentioned by Fried (2005), sports facilities construction boom that hit North America in the 1990s spread internationally.

In Malaysia image-transformation through hosting event and contribute to local communities through creating sports culture have been the centre point of sports investment. However, according to Gratton \& Taylor (1991), in the 1970s and 1980s, the sports facilities construction was to make an important contribution to local communities in welfare terms. Later 1980s, the rationale has changed to build prestigious sports-led development to promote regional and economic development (Davies 2002; Jones 2001; Lawless 1990; Loftman \& Nevin 1995) or aiming to transform the image of cities and turn them into major world cities (Gratton et al. 2005). With accordance to sports facilities construction boom in Malaysia, the findings of this research elaborate new considerations for town planners to determine the type of local environment for a new sports facility. Further, it may assist to review and provide specific guidelines and principles for sports facilities in Malaysia to follow the global trend in the future.

\section{REFERENCES}

Ahmad, F., Mohd, I., Maidin, S. L., Zainol, R., \& Noor, N. M. (2013). Malaysian Development Plan System: Issues and Problems, One Decade after its Reform (2001-2011), Journal of the Malaysian Institute of Planners, 11, 1-20.

Aman, M. S. (2005). Leisure Policy in New Zealand and Malaysia: A Comparative Study of Developments in Sport and Physical Recreation. New Zealand: Lincoln University, Phd Thesis.

Aminuddin, Y., \& Parilah, M. S. (2008). Globalization and the Malaysian Sports Industry. Research Journal of International Studies, 8, 112-116. 
Maassoumeh Barghchi \& Dasimah Omar

Town Planners' Perceptions of Sports Facilities and Urban Development: A Case Study of 13 States' Main Sports Facilities in Malaysia

Amran, A., \& Devi, S. S. (2008). The Impact of Government and Foreign Affiliate Influence on Corporate Social Reporting: The Case of Malaysia. Managerial Auditing Journal, 23(4), 386-404.

AMSCG (Aymeric Magne Stadia Consultation Group). (2009). Retrieved from http://ww w.b-ex.com/downloads/Aymeric\%20 Magne, \%20Stadia\%20Consulting.pdf

Beall, J., \& Fox, S. (2009). Cities and Development. USA and Canada: Routledge.

Brownfoot, J. N. (2003). 'Healthy Bodies, Healthy Minds'; Sport and Society in Colonial Malaya. International Journal of the History of Sport, 19 (2), 126-156.

Bunnell, T. (2004). Malaysia, Modernity and the Multimedia Super Corridor: a Critical Geography of Intelligent Landscape. London, UK: RoutledgeCurzon.

Chan, C. H. (1997). Forecasting the Structure of an Industrialising Economy. In B. N. Ghosh, Y. W. Lai, \& S. Narayanan, Industrialisation in Malaysia, Some Contemporary Issues. Kuala Lumpur, Malaysia: Utusan Publications and Distributors Sdn. Bhd.

Chapin, T. (1999). Urban Revitalisation Tools: Assessing the Impacts of Sports Stadia at the Microarea Level. Washington, USA: University of Washington, $\mathrm{PhD}$ Thesis.

Che' Man, N., Sabri, S., Hosni, N., \& Timmermans, H. (2013). Firm Dynamic Analysis for Urban Land Use and Economic Growth Modelling, Journal of the Malaysian Institute of Planners, Special Issue II, 57-74.

Chen, H. (2006). The Impact of Sports Events on Urban Development in PostMao China: A Case Study of Guangzhou. Oxford, Ohio, USA: Miami University, Master Thesis.

Cresswell, J. W. (2009). Research Design Qualitative, Quantitative and Mixed Methods Approaches. California, USA: SAGE.

Davies, L. (2005). Not in my Back Yard! Sports Stadia Location and the Property Market. Area Journal, 37 (3), 268-276.

Davies, L. (2002). Sport in the City: Measuring Economic Significance at the Local Level. European Sport Management Quarterly, 2 (2), 83-107.

Eisinger, P. (2000). The Politics of Bread and Circuses: Building the City for the Visitor Class. Urban Affairs Review, 35 (3), 316-333.

Fried, G. (2005). Managing Sport Facilities. Boston, USA: Human Kinetics.

Garvin, A. (2002). The American City: What Works, What Doesn't. New York, USA: Mc-Graw-Hill.

Government of Malaysia. (2010). Tenth Malaysia Plan, 2011-2015.

Government of Malaysia. (2006). Ninth Malaysia Plan, 2006-2010. 
Government of Malaysia. (1997). Ministry of Health Malaysia. National Health and Morbidity Survey, Institute of Public Health, Vol. 13, Exercise.

Government of Malaysia. (1991). Sixth Malaysia Plan, 1991-1995.

Government of Malaysia. (1988). National Sports Policy.

Gratton, C., Shibli, S., \& Coleman, R. (2005). Sport and Economic Regeneration in Cities. Journal of Urban Studies, 42 (5/6), 985-999.

Gratton, C., \& Taylor, P. (1991). Government and the Economics of Sport. Harlow, UK: Longman.

Haywood, L., Kew, F., \& Bramham, P. (1991). Understanding Leisure. Cheltenham: Stanley Thornes Ltd.

Horne, J., Tomlinson, A., \& Whannel, G. (1999). Understanding Sport: An Introduction to the Sociological and Cultural Analysis of Sport. London, UK: E. F. \& N. Spon.

John, G., Sheard, R., \& Vickery, B. (2007). Stadia: A Design and Development Guide. Germany: Architectural Press.

Jones, C. (2001). Mega-events and Host Region Impacts: Determining the True Worth of the 1999 Rugby World Cup. International Journal of Tourism Research, 3, 241-251.

Kim, K. K. (1985). Sportsmen in the Days of Yore. USA: New Straits Times.

King, R. (2008). Kuala Lumpur and Putrajaya: Negotiating Urban Space in Malaysia. Singapore: NUS Press.

Kumar, R. (2005). Research Methodology, step-by-step guide for beginners (2 ed.). Malaysia: SAGE.

Lai, Y. W. (1997). Determinants of Industrial Employment in Malaysia: 19681992. In B. N. Ghosh, Y. W. Lai, \& S. Narayanan, Industrialisation in Malaysia, Some Contemporary Issues. Kuala Lumpur, Malaysia: Utusan Publications and Distributors Sdn. Bhd.

Lawless, P. (1990). Regeneration in Sheffield: from Radical Intervention to Partnership. In D. Judd, \& M. Parkinson, Leadership and Urban Regeneration (133-150). London, UK: SAGE.

Loftman, P., \& Nevin, B. (1995). Prestige Projects and Urban Regeneration in the 1980's and 1990's: A Review of Benefits and Limitations. Planning Practice and Research, 3 (1), 31-39.

Megat Daud, M. A. K. (2007). Sport Management Movement in Malaysia. Asian Sport Management Review, 1 (1), 21-31.

Min, J., \& Jin, H. (2010). Analysis on Essence, Types and Characteristics of Leisure Sports. Modern Applied Science, 4(7), 99-103.

Moser, S. (2010). Putrajaya: Malaysia's New Federal Administrative Capital. Cities, 27 (4), 285-297.

Muda, M. (1998). The Significance of Commonwealth Games in Malaysia's Foreign Policy. Round Table, 346 (1). 
Maassoumeh Barghchi \& Dasimah Omar

Town Planners' Perceptions of Sports Facilities and Urban Development: A Case Study of 13 States' Main

Sports Facilities in Malaysia

Salleh, G. (2000). Urbanisation and Regional Development in Malaysia. Kuala Lumpur, Malaysia: Utusan Publications.

Sekaran, U. (2003). Research Methods for Business: A Skill Building Approach (4 ed.). New York, USA: John Wiley \& Sons.

Silk, M. (2002). Bangsa Malaysia: Global Sport, the City and the Mediated Refurbishment of Local Identities. Media Culture Society, 24 (6).

Suzuki, N. (2007). Sports and Neighborhood Regeneration: Exploring the Mechanisms of Social Inclusion through Sport. USA: University of Glasgow, PhD Thesis.

Thornly, A. (2002). Urban Regeneration and Sports Stadia. European Planning Studies, 10 (7), 813-818.

Westhuizen, J. (2004). Marketing Malaysia as a Model Modern Muslim State: the Significance of the 16th Commonwealth Games. Third World Quarterly, 25 (7), 1277-1291. 